\title{
Latitudinal variation in morphology in two sympatric damselfly species with contrasting range dynamics (Odonata: Coenagrionidae)
}

\author{
Christopher HASSALL, DAVID J. THOMPSON and IAN F. HARVEY
}

Biosciences Building, Crown Street, University of Liverpool, L69 7ZB Liverpool, UK; e-mail: c.hassall@liv.ac.uk

\begin{abstract}
Key words. Dragonfly, Odonata, Coenagrionidae, morphology, range shift, United Kingdom, body size, temperature, voltinism
\end{abstract}
\begin{abstract}
Geographic range expansion is one of the best documented macroecological consequences of climate change. A concomitant change in morphology has been demonstrated in some species. The relationship between latitudinal variation in morphology (e.g. Bergmann's rule) and the morphological consequences of microevolutionary pressures at expanding range margins have received little attention in the literature. Here we compare morphology of males of two Palaearctic damselfly (Odonata: Zygoptera) species, Coenagrion puella (Linnaeus, 1758) and Pyrrhosoma nymphula (Sulzer, 1776). C. puella has recently expanded its range from the north of England into Scotland. P. nymphula does not exhibit a range margin in the United Kingdom and has established populations in northern Scotland. We demonstrate evidence for spatially correlated variation in body size across the sampling sites between the two species but a deviation in patterns of dispersal-related morphology. $P$. nymphula exhibited very weak relationships between dispersal-related morphology (wing loading and thorax : abdomen mass ratio) and latitude. However, the more southerlydistributed C. puella exhibited strong relationships between mass investment in dispersal-related morphology and latitude. These trends appear to indicate compensatory growth patterns in cooler environments like those demonstrated for other species. The limits of this compensation for conditions that are close to the limits of a species' tolerance may contribute to the determination of the range margin. Greater variation in morphology towards the range margin has been observed in previous studies in Odonata. As such, the location of the sampling sites relative to the range margin of each species (closer in C. puella than P. nymphula) is highlighted as a potential contributing factor to the variation observed.
\end{abstract}

\section{INTRODUCTION}

There is little doubt now that, for whatever reason, the global climate is rapidly warming (Jones et al., 2001). This rapid climate change has resulted in a number of impacts on the earth's biota which have been welldocumented (Parmesan \& Yohe, 2003; Walther et al., 2005). One of the best described responses to this environmental change has manifested as a poleward shift in the geographic range of a range of taxa (Parmesan et al., 1999; Hickling et al., 2006).

Such variation in geographic ranges occurs through the dynamic processes of extinction and colonisation at range margins. Colonisation of new habitats at the range margin is achieved by a non-representative sample of the founding population, i.e. by those individuals that exhibit traits that confer an advantage in dispersal. Theoretically, therefore, there should be both a genetic (Hill et al., 2006) and phenotypic (Thomas et al., 2001; Phillips et al., 2006) footprint of range expansion detectable in those species that are responding to climate change.

However, the detection of a phenotypic footprint is complicated by the additional effects of latitude on morphology. This includes one of the first ecological rules formulated by Bergmann (1847) which stated that body size increased and limb length decreased with latitude. This rule has recently enjoyed a resurgence as the temperature-size rule (Atkinson, 1994). However, despite extensive recent study, there has been little success in elucidating the mechanisms behind this phenomenon (Angilletta Jr. \& Dunham, 2003; Walters \& Hassall, 2006).
Teasing apart the contribution that genetics makes to the phenotypic pattern has been accomplished using common garden experiments (Hill et al., 1999) and molecular techniques (Hill et al., 2006) in the speckled wood butterfly, Pararge aegeria (Linnaeus, 1758). However, the majority of range expansions occur along a north-south axis making it difficult to tease apart the effects of an expanding range and varying latitude.

The order Odonata has persisted through previous, rapid climatic shifts during the Quaternary Period (Adams et al., 1999). This suggests that the order should possess traits which will aid in future encounters with similar environmental change, such as that which is currently occurring (Balmford, 1996). Indeed, poleward range expansions have been documented in a range of European species (Ott, 2001; Hickling et al., 2006). The observation of contemporary range shifts is not surprising given the apparent constancy of other insect groups in the face of Quaternary climate fluctuations (Coope, 1978).

Odonate morphology has been studied in a range of contexts, including dispersal (Anholt, 1990; Conrad et al., 2002), landscape structure (Taylor \& Merriam, 1995), predator defences (Johansson \& Samuelsson, 1994), phylogenetics (O’Grady \& May, 2003) and latitude-size relationships (Johansson, 2003), as well as range expansion (Hassall et al., 2008). Johansson (2003) detected variation in body size across the latitudinal range in Enallagma cyathigerum, which highlights the importance of considering this aspect of morphology at the range margin. 

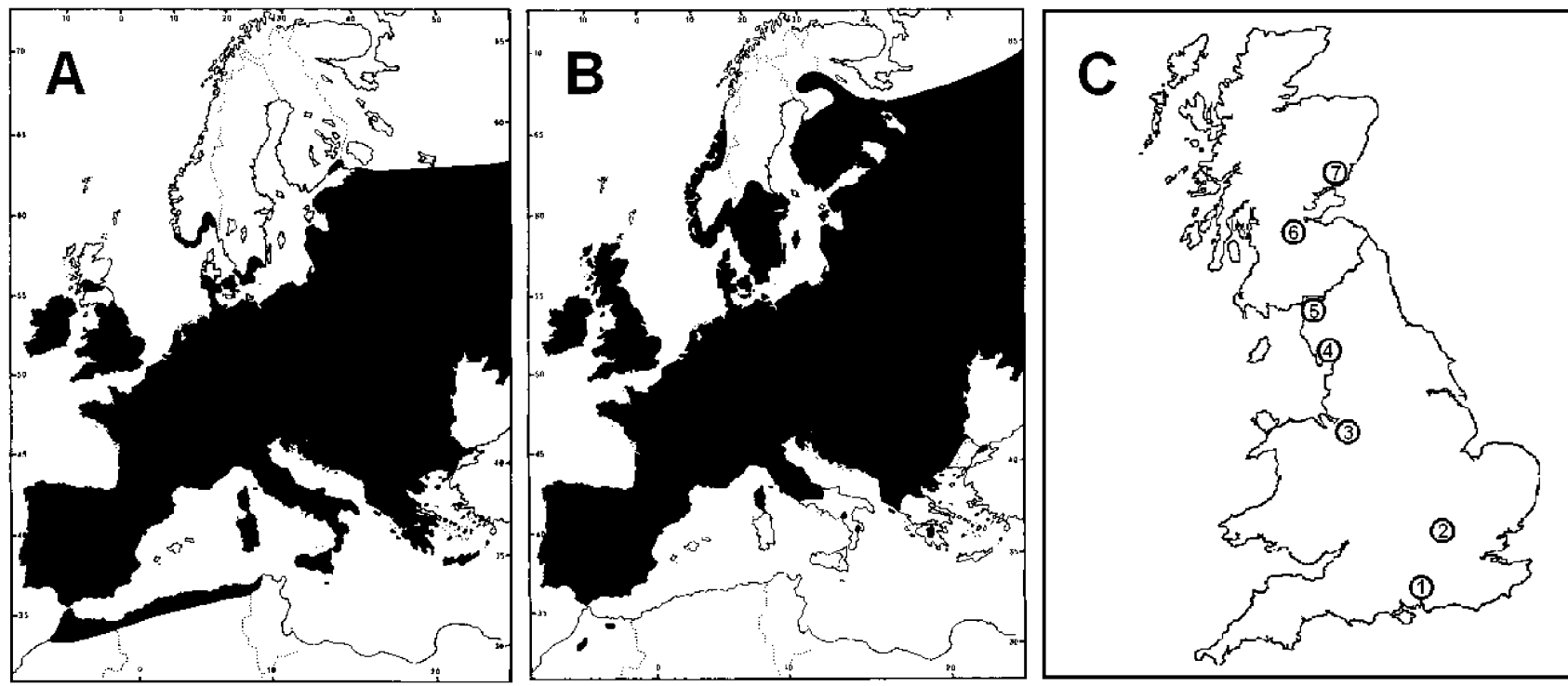

Fig. 1. Maps redrawn from Askew (2004) illustrating European ranges for Coenagrion puella (A) and Pyrrhosoma nymphula (B) and the UK sampling localities for both species $(\mathrm{C})$. Locality numbers in $(\mathrm{C})$ relate to locality numbers in Table 1.

We describe a comparative study of two common species of Palaearctic Odonata with overlapping distributions but which differ in their range dynamics. We demonstrate that a species that is not expanding its range [Pyrrhosoma nymphula (Sulzer, 1776)] exhibits little or no relationship between body size and flight morphology. However, a species that is expanding its range [Coenagrion puella (Linnaeus, 1758)] exhibits strong relationships with latitude in these traits. The direction of trends in C. puella appears to correspond to a compensation for declining muscular efficiency at lower temperatures close to the range margin.

\section{MATERIAL AND METHODS}

\section{Study species}

Coenagrion puella is a coenagrionid damselfly which is distributed throughout Europe (Fig. 1A). However, this species is only found in southern Scotland and is only found around the southern coast of Scandinavia. As such, it can be assumed that this species has the potential to expand its range into the north of the UK.

Pyrrhosoma nymphula is a coenagrionid damselfly which is also distributed throughout Europe including considerable areas of Scandinavia and northern Russia (Fig. 1B). Importantly, it has been recorded on or near the northern coast of Scotland since 1910 (Orkney Mainland, 58.97 $\mathrm{N}, 3.39^{\circ} \mathrm{E}$ ), suggesting that the species has long since filled available habitats within the UK.

\section{Sampling and measurement}

Sampling localities were selected to provide a latitudinal transect $640 \mathrm{~km}$ in length through the United Kingdom (Table 1 and Fig. 1C). Both species were sampled at each locality either within the same site where possible (three localities), or else at nearby pairs of sites (four localities). Note that $C$. puella was sampled at two different sites within locality 2 to provide a comparison within a locality.

Odonate body size has been shown to decline with time of season (Banks \& Thompson, 1985) and so care was taken to sample each site at the same time of season. To accomplish this, the British Dragonfly Society's extensive database of sightings was used to plot latitudinal variation in flight periods and sampling dates were specified accordingly (Fig. 2).

At least 30 males of each species were caught by the water body with a butterfly net and immediately preserved in ethanol for later processing. These specimens were then dissected and all four wings were preserved between pieces of adhesive tape. These were then scanned using a flatbed scanner and Image J (Rasband, 1997-2007) was used to make measurements of wing length and wing area on the resulting images.

TABLE 1. Summary of sampling sites for two species of damselfly in the UK.

\begin{tabular}{|c|c|c|c|c|c|c|}
\hline \multirow{2}{*}{ Locality } & \multicolumn{3}{|c|}{ Coenagrion puella } & \multicolumn{3}{|c|}{ Pyrrhosoma nymphula } \\
\hline & Site & Latitude & Longitude & Site & Latitude & Longitude \\
\hline 1 & QECP & 50.961 & -0.978 & QECP & 50.961 & -0.978 \\
\hline 2 & $\begin{array}{l}\text { Coronation Pit } \\
\text { Felmersham GP }\end{array}$ & $\begin{array}{l}52.083 \\
52.215\end{array}$ & $\begin{array}{l}-0.495 \\
-0.551\end{array}$ & Titchmarsh NR & 52.414 & -0.521 \\
\hline 3 & Vale Royal & 53.230 & -2.541 & Abbots Moss & 53.214 & -2.609 \\
\hline 4 & Duddon Mosses & 54.258 & -3.199 & Duddon Mosses & 54.258 & -3.199 \\
\hline 5 & Drumburgh Moss & 54.919 & -3.159 & Bowness Common & 54.928 & -3.207 \\
\hline 6 & Tailend Moss & 55.893 & -3.591 & Tailend Moss & 55.893 & -3.591 \\
\hline 7 & Loch of Kinnordy & 56.676 & -3.047 & Dykehead pond & 56.730 & -3.023 \\
\hline
\end{tabular}



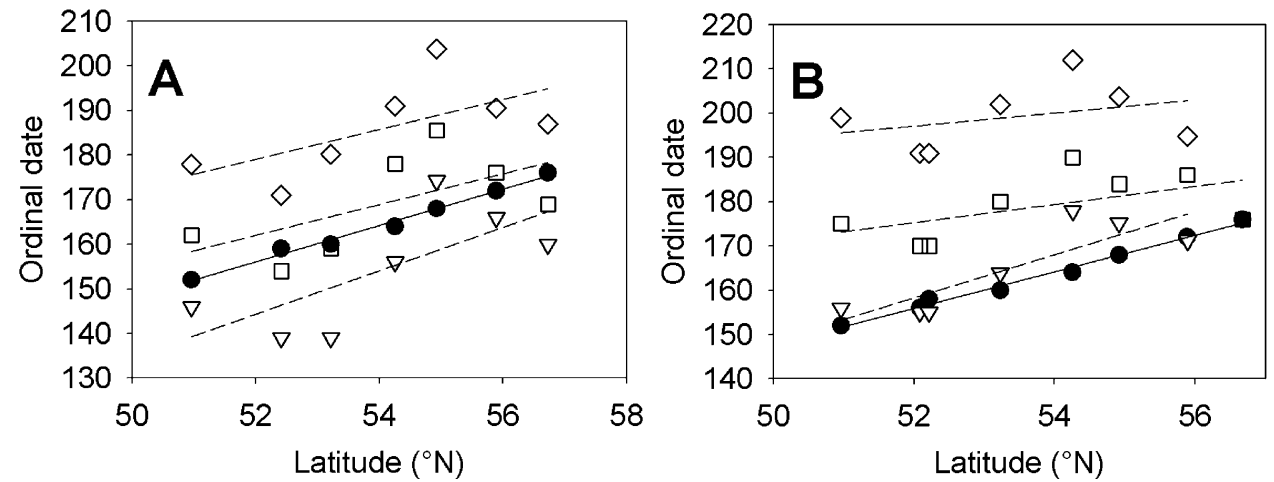

Fig. 2. Variation in flight period with latitude in (A) Pyrrhosoma nymphula and (B) Coenagrion puella. Dotted regression lines show Q1 (open triangles), Q2 (open squares) and Q3 (open diamonds) flight dates. Dates at which sites were sampled are shown by closed circles and a solid regression line. Phenology data are from 1995-2005.

Due to difficulties with defining the proximal portion of the wing around the wing plug, the area and length measurements only included the portion of the wing that lay distal to the first cross vein (Fig. 3). Repeated measurements from 35 randomly selected specimens were highly significantly correlated with first measurements (right forewing length, $\mathrm{r}=0.996, \mathrm{p}<0.001$ right forewing area, $\mathrm{r}=0.995, \mathrm{p}<0.001)$. The abdomen and thorax were dried at $60^{\circ} \mathrm{C}$ for $24 \mathrm{~h}$ and then weighed.

\section{Data analysis}

Aspect ratio of the wings was calculated for both hind- and forewings as wingspan ${ }^{2} /$ wing area and then used to calculate a mean aspect ratio for each individual. Wing loading was calculated as (thoracic mass + abdominal mass)/wing area, where wing area included all four wings. The ratio of thoracic and abdominal mass (hereafter "T : A ratio") was calculated by simply dividing the thoracic mass by the abdominal mass. Body mass was simply the sum of thoracic and abdominal mass and the right forewing was used as the representative wing length.

In order to investigate relative variations in the size of the measured traits, data were standardised to between zero and one. Means of each trait at each site were taken to eliminate the potential effects of pseudoreplication. To test for a difference between species, an ANCOVA was used to analyse each of the variables (wing length, body mass, wing loading, $\mathrm{T}: \mathrm{A}$ ratio and aspect ratio) with latitude as a covariate and species as a factor. For each species individually, linear regressions were used to test for effects of latitude on each of the variables. Equality of variance across sites was tested for in the wing length data using Bartlett's test as the data were normally distributed.

\section{RESULTS}

$P$. nymphula and $C$. puella differed significantly in size when all specimens were pooled (two-sample two-tailed t-test, wing length: $\mathrm{t}=14.13, \mathrm{p}<0.001$; body mass: $\mathrm{t}=$ 23.09, $\mathrm{p}<0.001)$. P. nymphula males possessed wings that measured on average $18.9 \mathrm{~mm} \pm 0.051($ mean $\pm \mathrm{SE})$

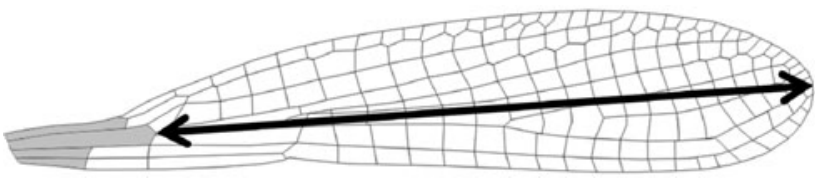

Fig. 3. Diagram of wing of Coenagrion puella showing wing length measurement (double-headed arrow) and region excluded from area measurement (shaded in grey). See text for details. compared to those of $C$. puella males that measured 17.9 $\mathrm{mm} \pm 0.047$. P. nymphula body mass was $8.33 \mathrm{mg} \pm$ 0.084 compared to $C$. puella which weighed $5.99 \mathrm{mg} \pm$ 0.057 .

Body mass and wing length increased with latitude in both $C$. puella and P. nymphula (Table 2, Figs $4 \mathrm{~A}$ and 4B), although this was not significant in the case of wing length. There was a significant species effect on the three dispersal traits (wing loading, $\mathrm{T}$ : A ratio and aspect ratio), as well as a significant effect of latitude on $\mathrm{T}: \mathrm{A}$ ratio (Table 2 ).

$P$. nymphula exhibited no significant correlations between any of the traits measured and latitude (Table 3 ). This is in contrast to the results for C. puella, which exhibited significant correlations with three traits (body mass, wing loading and $\mathrm{T}:$ A ratio, Table 3, Figs 4B-D). Positive correlations were found between latitude and $\mathrm{T}$ : A ratio and body mass in $C$. puella whereas a negative correlation was found between latitude and wing loading. It is worth noting that these three traits were those which involved mass measurements. The two traits relating solely to wing measurements (wing length and aspect ratio) did not vary significantly with latitude, although wing length approached significance $(\mathrm{p}=0.079)$.

Bartlett's test showed that there was no significant difference in variance across the latitudinal transect in $P$. nymphula $\left(\chi^{2}=6.92, \mathrm{p}=0.328\right.$; Fig. 5A). However, there was a significant difference in variance in C. puella $\left(\chi^{2}=\right.$ 22.4, $\mathrm{p}=0.002$; Fig. 5B). This variation in $C$. puella appears to involve a contraction of variance with

TABLE 2. Results of ANCOVAs investigating variations in four dispersal-related traits between species (C. puella and $P$. nymphula, as a factor) and with latitude (as a covariate).

\begin{tabular}{lcrlccc}
\hline \multirow{2}{*}{ Trait } & \multicolumn{2}{c}{ Species } & & \multicolumn{2}{c}{ Latitude } \\
\cline { 2 - 3 } \cline { 5 - 6 } & \multicolumn{1}{c}{$\mathrm{F}$} & \multicolumn{1}{c}{$\mathrm{P}$} & & $\mathrm{F}$ & $\mathrm{P}$ \\
\hline Wing length & 0.08 & 0.785 & & 4.63 & 0.053 \\
Body mass & 2.90 & 0.114 & & 8.89 & 0.011 \\
Wing loading & 23.99 & $<0.001$ & & 1.39 & 0.262 \\
T : A ratio & 12.67 & 0.004 & & 8.60 & 0.013 \\
Aspect ratio & 456.18 & $<0.001$ & & 1.09 & 0.318 \\
\hline
\end{tabular}



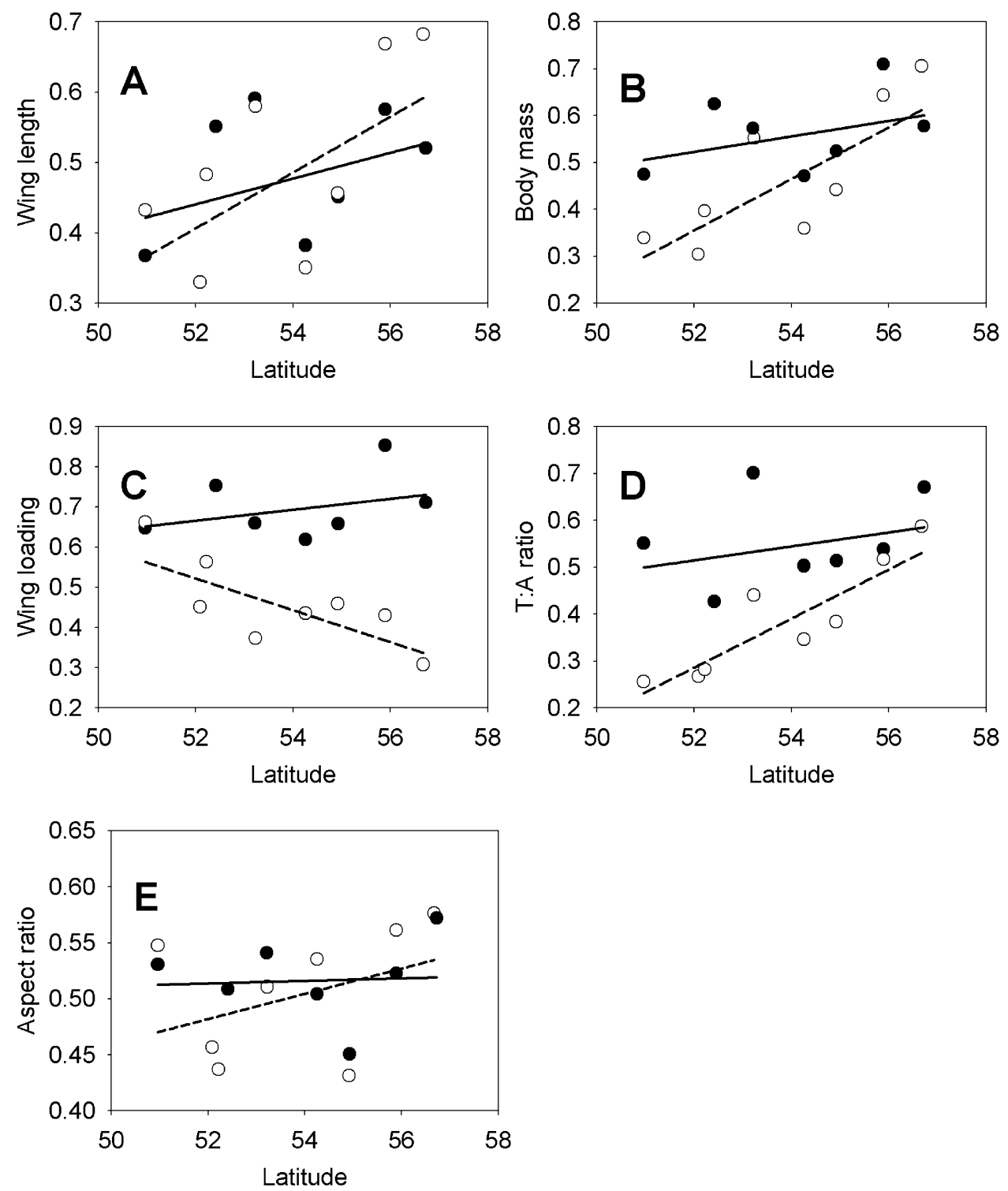

Fig. 4. Mean values of (A) wing length, (B) body mass, (C) wing loading, (D) T : A ratio and (E) aspect ratio for Coenagrion puella (open circles, dotted lines) and Pyrrhosoma nymphula (closed circle, solid lines) at each site plotted against the latitude of that site. Lines are linear regressions (see Table 3 for statistics).

increasing latitude in the four southern sites (Fig. 5B). The fifth site then reverts to a variance similar to that of the first site followed by a renewed trend towards declining variance.

TABLE 3. Correlations between dispersal-related traits and latitude in two species of damselfly. Significant correlations are highlighted in bold.

\begin{tabular}{lrrrcc}
\hline \multirow{2}{*}{ Trait } & \multicolumn{2}{c}{ C. puella $(\mathrm{n}=8)$} & & \multicolumn{2}{c}{ P. nymphula $(\mathrm{n}=7)$} \\
\cline { 2 - 3 } \cline { 5 - 6 } & $\mathrm{r}$ & $\mathrm{p}$ & & $\mathrm{r}$ & $\mathrm{p}$ \\
\hline Wing length & 0.653 & 0.079 & & 0.340 & 0.455 \\
Body mass & $\mathbf{0 . 8 0 8}$ & $\mathbf{0 . 0 1 5}$ & & 0.408 & 0.364 \\
Wing loading & $\mathbf{- 0 . 7 7 5}$ & $\mathbf{0 . 0 2 4}$ & & 0.377 & 0.405 \\
T : A ratio & $\mathbf{0 . 9 0 2}$ & $\mathbf{0 . 0 0 2}$ & & 0.105 & 0.823 \\
Aspect ratio & 0.397 & 0.330 & & 0.284 & 0.538 \\
\hline
\end{tabular}

\section{DISCUSSION}

$P$. nymphula, a species that has been established throughout the UK for at least a century, exhibited no significant trends with latitude in any of two size measurements (body mass and wing length) or three dispersal-related traits (wing loading, $\mathrm{T}: \mathrm{A}$ ratio and aspect ratio). However, C. puella, a species that is known to be expanding its range into mid-Scotland, exhibited significant latitudinal relationships with body mass, wing loading and $\mathrm{T}$ : A ratio. Body mass and wing length both increased with increasing latitudes, in line with expectations from the temperature-size rule. Variation in wing loading and $\mathrm{T}$ : A ratio appears to follow the pattern that would be expected if these two traits were compensating for decreased flight muscle efficiency at lower temperatures. Both of these traits have been associated with flight acceleration in Lepidoptera (Berwaerts et al., 2002). 

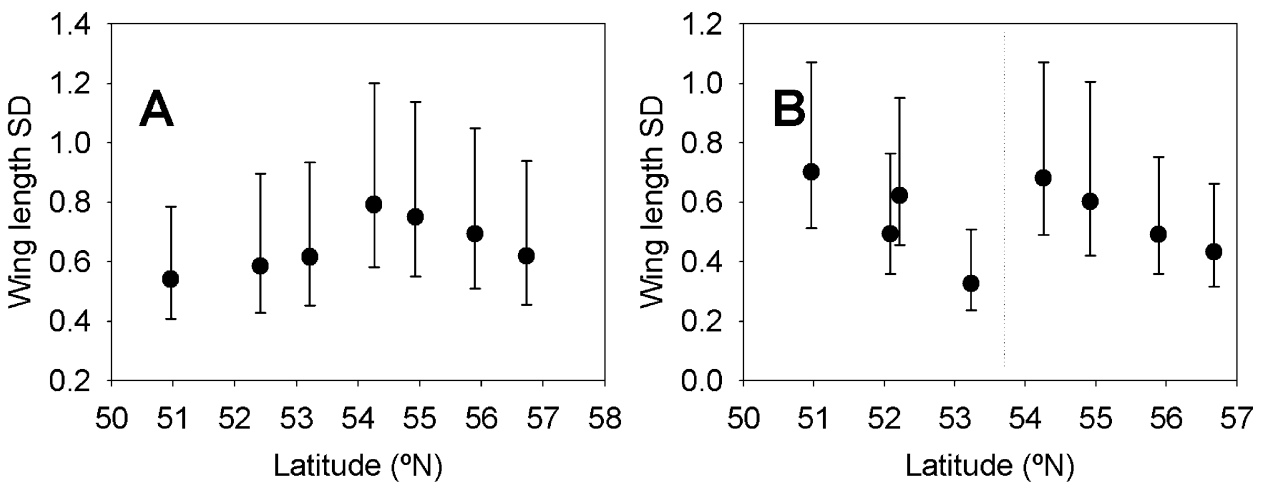

Fig. 5. Trends in standard deviation in body size (right forewing length) across a latitudinal gradient in (A) male Pyrrhosoma nymphula and (B) male Coenagrion puella. Bars are 95\% CI. Dotted, vertical line in (B) represents division of populations into two putative voltinism categories.

$\mathrm{T}:$ A ratio could potentially reflect the relative apportioning of investment between reproduction (abdomen) and dispersal (thorax) in females and has been linked to colonisation ability in Lepidoptera (Hill et al., 1999). However, latitude-size relationships would mean that males would be predicted to exhibit the same pattern, to increase the mass of flight muscle relative to the rest of the body. Thoracic mass correlates with the amount of energy produced per wing stroke in Anisoptera (May, 1981).

The decline in wing loading is particularly significant, since an increase in size (along all linear dimensions) would be expected to produce an increase in the amount of mass (proportional to volume, length ${ }^{3}$ ) per unit area of wing $\left(\right.$ length ${ }^{2}$ ). Wing loading has been shown to be positively associated with latitude in European Drosophila subobscura (Collin, 1936) (Gilchrist \& Huey, 2004), as has wing aspect ratio in Drosophila melanogaster (Meigen, 1830) (Azevedo et al., 1998).

Studies across the entire latitudinal range of Enallagma cyathigerum (Charpentier, 1840) suggested a U-shaped relationship between body size and latitude (Johansson, 2003). It may be that the location of the sampled latitudinal transect relative to the range margins of each species has determined the extent of variation in size that was detected. In the present study $P$. nymphula was sampled closer to the central depression of the U-shape, whereas C. puella was sampled at the extreme of an ascending limb. However, it is important to note that there is a range of other factors that have also been shown to influence odonate body size, including prey density (Lawton et al., 1980), seasonal time constraints (Johansson \& Rowe, 1999; De Block \& Stoks, 2003) and predation (Blumenshine et al., 2000).

The patterns of variance in the body size measurements for $C$. puella may be indicative of a shift in voltinism generated by seasonal time constraints. Such a pattern of variance has not been reported before, although it may be present in data from other studies (e.g., Johansson, 2003). Such a pattern in declining body size variance could result from increasing physiological pressure from photoperiod to accelerate growth with decreasing length of growth season. Of the range of growth rates that are pos- sible within a population, a proportion of the lowest which would not have made the winter critical size (Norling, 1984) are accelerated, thus reducing the variance.

The latitude of the voltinism shift predicted from the present data on C. puella (between $53.23^{\circ} \mathrm{N}$ and $54.26^{\circ} \mathrm{N}$, marked approximately by the dotted vertical line in Fig. 5B) concurs with the field studies which show univoltinism between $41.73^{\circ} \mathrm{N}$ and $48.27^{\circ} \mathrm{N}$ with a "split cohort" (both uni- and semivoltinism) recorded at $53.47^{\circ} \mathrm{N}$ (see appendix in Corbet et al., 2006) and at three ponds between $53.00^{\circ} \mathrm{N}$ and $53.35^{\circ} \mathrm{N}$ (Banks, 1985). It would be assumed that any population north of this point would be purely semivoltine, although none has been recorded. It is reasonable to assume that climate change has resulted in a poleward shift in voltinism thresholds over the time since Banks' data were collected.

By way of contrast, $P$. nymphula is generally considered to be uniformly semivoltine across its British range, with some northern populations taking three years per generation at high densities (Macan, 1964, 1974). Univoltinism has been recorded at $47^{\circ} \mathrm{N}$ and semivoltinism recorded between $50.82^{\circ} \mathrm{N}$ and $56.73^{\circ} \mathrm{N}$ (Dykehead pond) (again, see Corbet et al., 2006 for details). However, no new studies have been carried out in southern England since 1993.

\section{CONCLUSION}

Damselflies vary in the relationship between latitude and morphology. This result may be due to the location of sampling sites relative to each of the species' ranges. The data supports a variation in the gradient of the latitudesize relationship which is in agreement with those trends detected in previous studies (Johansson, 2003). C. puella, the species sampled at its range margin, showed strong latitudinal variation in mass and three dispersal traits with the direction of variation suggesting a trend towards compensation for decreased flight muscle efficiency at higher latitudes (lower temperatures). Also in this species, evidence was found for an effect of growth season and photoperiod on body size distributions suggesting a progressive homogenisation of development rates at increasing time stress. 
ACKNOWLEDGEMENTS. We would like to thank the landowners, including The Wildlife Trusts, O\&H Properties, RSPB, Forestry Commission of Great Britain and Airlie Estates, for access to sampling sites. E. Aimé provided invaluable assistance with fieldwork. $\mathrm{CH}$ was supported by a Natural Environment Research Council Studentship.

\section{REFERENCES}

Adams J., Maslin M. \& Thomas E. 1999: Sudden climate transitions during the Quaternary. Progr. Physic. Geogr. 23: 1-36.

Angilletta JR. M.J. \& Dunham A.E. 2003: The temperaturesize rule in ectotherms: simple evolutionary explanations may not be general. Am. Nat. 162: 332-342.

AnHolt B.R. 1990: Size-biased dispersal prior to breeding in a damselfly. Oecologia 83: 385-387.

Askew R.R. 2004: The Dragonflies of Europe. 2nd ed. Harley, Colchester, $308 \mathrm{pp}$.

AtKinson D. 1994: Temperature and organism size - a biological law for ectotherms? Adv. Ecol. Res. 25: 1-58.

Azevedo R.B.R., James A.C., McCabe J. \& Partridge L. 1998: Latitudinal variation of wing : thorax size ratio and wingaspect ratio in Drosophila melanogaster. Evolution 52: $1353-1362$.

BALMFORD A. 1996: Extinction filters and current resilience: the significance of past selection pressures for conservation biology. Trends Ecol. Evol. 11: 193-196.

Banks M.J. 1985: Population Dynamics and Lifetime Reproductive Success of Damselflies. $\mathrm{PhD}$ thesis, University of Liverpool, Liverpool.

BAnKs M.J. \& Thompson D.J. 1985: Emergence, longevity and breeding area fidelity in Coenagrion puella (L.) (Zygoptera: Coenagrionidae). Odonatologica 14: 279-286.

BergmanN C. 1847: Über die verhaltnisse der warmeokonomie der thiere zu ihrer grosse. [Concerning the relationship of heat conservation of animals to their size.] Götting. Stud. 1: 595-708.

Berwaerts K., Van Dyck H. \& Aerts P. 2002: Does flight morphology relate to flight performance? An experimental test with the butterfly Pararge aegeria. Funct. Ecol. 16: 484-491.

Blumenshine S.C., Lodge D.M. \& Hodgson J.R. 2000: Gradient of fish predation alters body size distributions of lake benthos. Ecology 81: 374-386.

Conrad K.F., Willson K.H., Whifield K., Harvey I.F., Thomas C.J. \& Sherratt T.N. 2002: Characteristics of dispersing Ischnura elegans and Coenagrion puella (Odonata): Age, sex, size, morph and ectoparasitism. Ecography 25: 439-445.

Coope G.R. 1978: Constancy of insect species versus inconstancy of Quaternary environments. In Mound L.A. \& Waloff N. (eds): Diversity of Insect Faunas. Blackwell Scientific Publications, Oxford, pp. 176-187.

Corbet P.S., Suhling F. \& Söndgerath D. 2006: Voltinism of Odonata: a review. Int. J. Odonatol. 9: 1-44.

De Block M. \& Stoks R. 2003: Adaptive sex-specific life history plasticity to temperature and photoperiod in a damselfly. J. Evol. Biol. 16: 986-995.

Gilchrist G.W. \& Huey R.B. 2004: Plastic and genetic variation in wing loading as a function of temperature within and among parallel clines in Drosophila subobscura. Intergr. Compar. Biol. 44: 461-470.

Hassall C., Thompson D.J. \& Harvey I.F. 2008: Wings of Coenagrion puella vary in shape at the northern range margin (Odonata: Coenagrionidae). Int. J. Odonatol. 11: 35-41.

Hickling R., Roy D.B., Hill J.K., Fox R. \& Thomas C.D. 2006: The distributions of a wide range of taxonomic groups are expanding polewards. Glob. Change Biol. 12: 1-6.
Hill J.K., Thomas C.D. \& Blakeley D.S. 1999: Evolution of flight morphology in a butterfly that has recently expanded its geographic range. Oecologia 121: 165-170.

Hill J.K., Hughes C.L., Dytham C. \& Searle J.B. 2006: Genetic diversity in butterflies: interactive effects of habitat fragmentation and climate-driven range expansion. Biol. Letters 2: 152-154.

JoHANSSON F. 2003: Latitudinal shifts in body size of Enallagma cyathigerum (Odonata). J. Biogeogr. 30: 29-34.

JohANSSON F. \& Rowe L. 1999: Life history and behavioral responses to time constraints in a damselfly. Ecology 80: $1242-1252$.

JoHANSSON F. \& SAMUELSSON L. 1994: Fish-induced variation in abdominal spine length of Leucorrhinia dubia (Odonata) larvae? Oecologia 100: 74-79.

Jones P.D., Osborn T.J. \& Briffa K.R. 2001: The evolution of climate over the last millennium. Science 292: 662-667.

Lawton J.H., Thompson B.A. \& Thompson D.J. 1980: The effects of prey density on survival and growth of damselfly larvae. Ecol. Entomol. 5: 39-51.

MACAN T.T. 1964: The Odonata of a moorland fishpond. Int. Rev. Gesam. Hydrobiol. 49: 325-360.

MACAN T.T. 1974: Twenty generations of Pyrrhosoma nymphula (Sulzer) and Enallagma cyathigerum (Charpentier) (Odonata: Zygoptera). Odonatologica 3: 107-119.

MAY M.L. 1981: Wingstroke frequency of dragonflies (Odonata: Anisoptera) in relation of temperature and body size. $J$. Compar. Physiol. (B) 144: 229-240.

Norling U. 1984: Life history patterns in the northern expansion of dragonflies. Adv. Odonatol. 2: 127-156.

O'Grady E.W. \& May M.L. 2003: A phylogenetic reassessment of the subfamilies of Coenagrionidae (Odonata: Zygoptera). J. Nat. Hist. 37: 2807-2834.

Отт J. 2001: Expansion of Mediterranean Odonata in Germany and Europe - Consequences of climatic changes. In Walther G.R., Buga C. \& Edwards P.J. (eds): "Fingerprints" of Climate Change: Adapted Behaviour and Shifting Species Ranges, Kluwer Academic/Plenum Publishers, New York, pp. 89-112.

Parmesan C. \& Yohe G. 2003: A globally coherent fingerprint of climate change impacts across natural systems. Nature 421: $37-42$.

Parmesan C., Ryrholm N., Stefanescu C., Hill J.K., Huntley B., Thomas C.D., Descimon H., Kalla L., Kullberg J., Tammaru T., Tennent W.J., Thomas J.A. \& Warren M. 1999: Poleward shifts in geographical ranges of butterfly species associated with regional warming. Nature 399: 579-583.

Phillips B.L., Brown G.P., Webi J.K. \& Shine R. 2006: Invasion and the evolution of speed in toads. Nature 439: 803 .

RASBAND W.S. 1997-2007: ImageJ. <http://rsb.info.nih.gov/ij/>, National Institutes for Health, Bethesda, Maryland, USA.

TAYlor P.D. \& Merriam G. 1995: Wing morphology of a forest damselfly is related to landscape structure. Oikos 73: 43-48.

Thomas C.D., Bodsworth E.J., Wilson R.J., Simmons A.D., Davies Z.G., Musche M. \& ConRadt L. 2001: Ecological and evolutionary processes at expanding range margins. Nature 411: $577-581$.

Walters R.J. \& Hassall M. 2006: The temperature size rule in ectotherms: may a general explanation exist after all? Am. Nat. 167: 510-523.

Walther G.R., Berger S. \& Sykes M.T. 2005: An ecological "footprint" of climate change. Proc. R. Soc. Lond. (B) 272: 1427-1432.

Received August 4, 2008; revised and accepted October 2, 2008 